this work for many years in spite of his failing health due to long-standing diabetes. Having for some time conducted seminars on counselling patients with diabetic retinopathy at King's College Hospital, it was all the more tragic that he had to retire because in the end he himself lost his sight. He will be missed by many who benefited from his humane approach to medicine and psychiatry. He leaves two sons, one of whom is a doctor, and a daughter who has recently become a member of the College.

HW

WILLIAM SARGANT, Emeritus Consultant, St
Thomas's Hospital, London

William Sargant died at the age of 81 on 27 August 1988. He was a striking personality. Well over $6 \mathrm{ft}$ and broadly built, he had tremendous charisma and authority; above all he wanted to alleviate suffering. His father $-\mathrm{a}$ strong Methodist, whose hero was John Wesley - had a considerable influence on his character, and in shaping his principles and his ambivalent attitude to authority and the Establishment.

Sargant was successful in any field into which he wholeheartedly threw himself. After a successful start at St Mary's, he looked destined to become a physician, until depression and pulmonary tuberculosis diverted him into psychiatry. He became a locum at Hanwell, and was appalled by what he saw of patients' sufferings and the indifference of the staff. He joined the Maudsley, one of the group of outstanding psychiatrists gathered together by Professor Edward Mapother, and quickly established a reputation as both brilliant and explorative; he demonstrated the value of benzedrine in certain types of depression and he was among the first to use cardiazol convulsions and deep insulin therapy. His opposition to psychoanalysis was implacable but always tinged with humour, and he admired Freud as a thinker. One of his hopes was to treat a patient analysed by Freud, but the only time he met one, the patient had had too much ECT to be able to recall his analysis! In 1938 he was awarded a Rockefeller Fellowship to Harvard, and was in the USA at the outbreak of war. He hurried back to England and rejoined the Maudsley, which had been split into two parts. Sargant joined the half at Sutton Emergency Hospital, later Belmont Hospital, and there worked with psychiatrists of the calibre of Slater, Shorvon, and Minski, and developed effective techniques for treating shell-shocked combatants-barbiturate abreactions, heavy sedation and narcosis, and modified insulin to restore weight - the principles of which still stand. In 1944, with Slater, he published an Introduction to Physical Methods of Treatment in Psychiatry, which for many years was the bible of psychiatrists worldwide.

In 1948 he took charge of the Psychiatric Department at St Thomas's Hospital. The effect there was dramatic and within a few years his department was highly sought after by patients and junior psychiatrists. He was an inspiring teacher, and many of his students took up psychiatry as their career.

Sargant worked at pressure - and smoked $40+$ a day at one time - and was prone to spells of moodiness when events went wrong. In 1954 he became depressed and had a second, more serious, bout of tuberculosis. In some ways this forced 'sabbatical' did him enormous good during which he wrote Battle for the Mind. He returned to St Thomas's Hospital with renewed zest, and produced numerous papers, especially on the antidepressants, and lectured extensively.

He was Registrar of the old Royal Medico Psychiatric Association from 1952-71, President of the Section of Psychiatry of the Royal Society of Medicine, and helped to create the World Psychiatric Association. Initially opposed to the formation of the Royal College, he eventually accepted the majority's wish. Perhaps he was too individualistic for the College to vote him their first President. It was a pity. He was elected a Foundation Fellow in 1971 and an Honorary Fellow in 1973.

He married Peggy in 1940, and drew much strength from her. She survives him.

PD

\section{BARONESS WOOTTON OF ABINGER, CH}

Baroness Wootton of Abinger, perhaps the most distinguished social scientist of her time, died on 11 July 1988 at the age of 91 .

Barbara Frances Wootton was born into an illustrious Cambridge academic family. She herself took a brilliant degree in economics at Cambridge, and later became a Fellow of Girton and so seemed set to follow her parents into the academic establishment.

Her entire life was catastropically altered, however, by the personal losses she sustained in the First World War, losses which scarred her emotionally for the rest of her long life. Her husband was recalled to his regiment a matter of hours after their wedding: he was killed in action in France five weeks later. She had already suffered the loss of her brother, killed in 1916, together with countless others of her male contemporaries. In 1935 she married for the second time, 